\title{
Nutrient regulation of glucagon secretion: involvement in metabolism and diabetes
}

\author{
Laura Marroquí ${ }^{1,2}$, Paloma Alonso-Magdalena ${ }^{1,3}$, Beatriz Merino ${ }^{1,3}$, Esther Fuentes ${ }^{1,3}$, \\ Angel Nadal ${ }^{1,3}$ and Ivan Quesada ${ }^{1,3 *}$ \\ ${ }^{1}$ Instituto de Bioingeniería, Universidad Miguel Hernández, Elche, Spain \\ ${ }^{2}$ Laboratory of Experimental Medicine, Université Libre de Bruxelles, Brussels, Belgium \\ ${ }^{3}$ CIBER de Diabetes y Enfermedades Metabólicas Asociadas (CIBERDEM), Barcelona, Spain
}

\begin{abstract}
Glucose homeostasis is precisely regulated by glucagon and insulin, which are released by pancreatic $\alpha$ - and $\beta$-cells, respectively. While $\beta$-cells have been the focus of intense research, less is known about $\alpha$-cell function and the actions of glucagon. In recent years, the study of this endocrine cell type has experienced a renewed drive. The present review contains a summary of established concepts as well as new information about the regulation of $\alpha$-cells by glucose, amino acids, fatty acids and other nutrients, focusing especially on glucagon release, glucagon synthesis and $\alpha$-cell survival. We have also discussed the role of glucagon in glucose homeostasis and in energy and lipid metabolism as well as its potential as a modulator of food intake and body weight. In addition to the well-established action on the liver, we discuss the effects of glucagon in other organs, where the glucagon receptor is expressed. These tissues include the heart, kidneys, adipose tissue, brain, small intestine and the gustatory epithelium. Alterations in $\alpha$-cell function and abnormal glucagon concentrations are present in diabetes and are thought to aggravate the hyperglycaemic state of diabetic patients. In this respect, several experimental approaches in diabetic models have shown important beneficial results in improving hyperglycaemia after the modulation of glucagon secretion or action. Moreover, glucagon receptor agonism has also been used as a therapeutic strategy to treat obesity.
\end{abstract}

Key words: Pancreatic $\boldsymbol{\alpha}$-cells: Diabetes: Glucagon secretion

\section{Introduction}

Glucose homeostasis is mainly controlled by the islets of Langerhans, which constitute the endocrine portion of the pancreas. About one million islets are distributed throughout the exocrine pancreas in an adult human. The size of these multicellular structures varies from 50 to $500 \mu \mathrm{m}$. They are composed of 1000-2000 different types of cells, which secrete several cell-specific hormones and peptides in response to nutrients: glucagon is released from $\alpha$-cells, insulin from $\beta$-cells, somatostatin from $\delta$-cells, pancreatic polypeptide from PP-cells and ghrelin from $\varepsilon$-cells ${ }^{(1,2)} . \alpha$ - and $\beta$-Cells are the most abundant islet cell types. In rodents, glucagon- and insulin-releasing cells constitute about $15-20 \%$ and $60-80 \%$ of the total islet population, respectively, although the proportion of each cell type may vary depending on the anatomical portion of the pancreas ${ }^{(1,2)}$. While $\beta$-cells are mostly integrated in the central core of the islet, $\alpha$-cells are around the periphery forming a cell mantle. However, the $\alpha$-cell population in humans is up to $45 \%$ of the islet and is distributed in patches throughout the whole islet, frequently juxtaposed to $\beta$-cells. While intercellular communication via gap junctions is frequent in $\beta$-cells, leading to synchronised responses like a syncitium, $\alpha$-cells work individually without apparent intercellular coupling ${ }^{(3,4)}$. These cytoarchitecture features along with results of microcirculatory flow studies suggest that there is an important intercellular communication conduit from $\beta$ - to $\alpha$-cells ${ }^{(5)}$, in which paracrine interactions play a prominent role ${ }^{(6)}$. An extensive capillary network throughout the islet ${ }^{(2)}$ allows for a rapid sensing of changes in plasma nutrients and signalling molecules, triggering the subsequent secretory responses. Additionally, islet cells, particularly $\alpha$-cells, are subjected to a precise regulation through a highly innervated sympathetic and parasympathetic system that extends through the perivascular spaces. This neural network has a critical function in rapid islet secretory responses, particularly under hypoglycaemic conditions ${ }^{(7,8)}$. Thus, among the numerous signalling levels that regulate the secretory capacity of islet cells, nutrients are a major player.

Abbreviations: AAMPK, AMP-activated protein kinase; CAMP, cyclic AMP; FGF21, fibroblast growth factor 21; GLP-1, glucagon-like peptide-1; $\mathrm{K}_{\mathrm{ATP}}$, ATP-dependent $\mathrm{K}^{+}$; KO, knockout; MAPK, mitogen-activated protein kinase; PC, prohormone convertase; PKA, protein kinase A.

*Corresponding author: Dr I. Quesada, +34 96522 2033, email ivanq@umh.es 
Changes in plasma glucose levels are one of the main control inputs for the release of glucagon and insulin. In pancreatic $\beta$-cells, high glucose levels induce the intracellular uptake of the carbohydrate, triggering the coupling between intracellular metabolic signals and the insulin secretory output. Insulin receptors are then activated by increased plasma insulin levels, leading to the uptake of glucose and its accumulation as glycogen or fat in muscle, liver and adipose tissue. This process leads to a decrease in plasma glucose concentrations until they reach basal levels. In contrast, pancreatic $\alpha$-cells release glucagon more actively in hypoglycaemic conditions. This hormone binds to its receptors in the liver, the main target organ of glucagon, and activates hepatic gluconeogenesis and glycogenolysis ${ }^{(9,10)}$. As a consequence, hepatic glucose is released to the bloodstream, allowing for a restoration of plasma glucose levels. Since insulin and glucagon share some target organs but have opposite roles, the final effect of both hormones depends on the insulin:glucagon ratio. In addition to glucose, plasma lipids and amino acids also regulate hormonal release from both cell types and, at the same time, insulin and glucagon act on fat and protein metabolism ${ }^{(11-14)}$, as will be discussed later. All these processes are impaired in diabetes mellitus. This metabolic disease is not only the result of insulin secretory abnormalities, the loss of $\beta$-cell mass and peripheral insulin resistance but it is also the outcome of altered glucagon release as well as $\alpha$-cell mass changes ${ }^{(15)}$. Despite the importance of glucagon secretion, understanding of the function of $\alpha$-cells in health and diabetes has remained elusive for a long time. This limited information was mainly due to the scarcity of $\alpha$-cells within the islets of common animal models, the low availability of glucagon-releasing cell lines, the lack of physiological patterns for the recognition of this cell type and several limitations of the available techniques and methodologies. However, in the last decade, the biology of the pancreatic $\alpha$-cell has experienced a renaissance due to technical advances along with the development of several experimental strategies based on the modulation of glucagon secretion and/or action that may be helpful in the treatment of diabetes and other endocrine disorders. In the present review, all these aspects will be discussed.

\section{Nutrient regulation of pancreatic $\alpha$-cells}

Among the multiple control levels that regulate pancreatic $\alpha$-cell function, nutrients exert a primary role (Fig. 1). Nutrients modulate pancreatic $\alpha$-cell secretion, glucagon gene expression, cell proliferation and cell death.

\section{Glucose}

One of the main stimuli that modulate glucagon secretion is plasma glucose. The ingestion, injection or infusion of glucose in animal models and human subjects has been

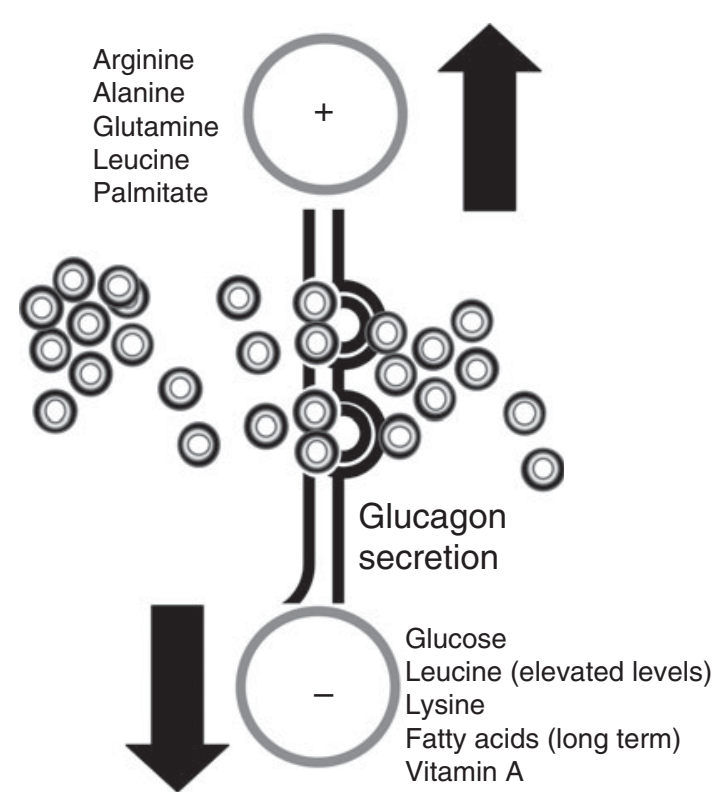

Fig. 1. Nutrient regulation of glucagon secretion. The stimulatory $(+)$ and inhibitory (-) effects of different nutrients on glucagon release by pancreatic $\alpha$-cells are shown. For further information, see the text.

proven to suppress glucagon secretion, while decreased plasma glucose levels are correlated with enhanced glucagon release ${ }^{(10,16,17)}$. Similarly, in vitro experiments have shown that glucagon release is stimulated in hypoglycaemic conditions, whereas high glucose levels down-regulate $\alpha$-cell secretory activity ${ }^{(18,19)}$. Pancreatic $\alpha$-cells are excitable cells able to respond to changes in extracellular glucose concentrations. At low glucose levels, these cells develop action potentials that trigger intracellular $\mathrm{Ca}$ signals and glucagon secretion in rodent and human islets $^{(3,4,20-22)}$. In contrast, hyperglycaemic conditions inhibit $\alpha$-cell functional activity, lowering glucagon release ${ }^{(9)}$. This glucose modulation may rely on different control levels: the neural sensing of glucose and the subsequent neural regulation of $\alpha$-cells ${ }^{(23,24)}$, the sensing of glucose by neighbouring $\beta$ - and $\delta$-cells within the islet and the inhibition of pancreatic $\alpha$-cells by paracrine regulation (see the following sections) and, lastly, the glucose sensing and intracellular metabolism directly by pancreatic $\alpha$-cells ${ }^{(25)}$. The latter possibility has been the subject of intense debate. While some studies indicate that ATP-dependent $\mathrm{K}^{+}\left(\mathrm{K}_{\mathrm{ATP}}\right)$ channels play a central role in coupling glucose-modulated metabolic changes with pancreatic $\alpha$-cell electrical activity and secretion ${ }^{(25,26)}$, other reports support a $\mathrm{K}_{\mathrm{ATP}}$-independent glucose effect ${ }^{(27-29)}$. Some of these controversies have emerged from studies of $\alpha$-cell metabolism. The analysis of mitochondrial membrane potential, NADH autofluorescence or direct measurements of cytosolic ATP levels have shown both measurable and negligible glucose-induced changes in $\alpha$-cell metabolism ${ }^{(4,29-31)}$. In this regard, it has been described that glucose-induced ATP/ADP changes in $\alpha$-cells are very low compared with the ones in $\beta$-cells, probably because of the biochemical 
differences existing between both islet cell types ${ }^{(32)}$. In experiments with either samples of non- $\beta$-cells or purified $\alpha$-cells, it has been determined that GLUT-1 is the highaffinity, low-capacity GLUT present in $\alpha$-cells, in contrast to GLUT-2, which is present in $\beta$-cells. Despite this difference, this metabolic step is not a limiting factor in $\alpha$-cell glucose utilisation $^{(33,34)}$. Other biochemical differences between both cell types also suggest that $\alpha$-cells are less competent in the use they make of mitochondrial glucose oxidation $^{(4,35)}$. In fact, compared with pancreatic $\beta$-cells, non- $\beta$-cells exhibit a higher expression of the lactate/monocarboxylate transporter and a lower expression of pyruvate carboxylase ${ }^{(36,37)}$. Additionally, non- $\beta$-cells present higher rates of lactate dehydrogenase activity, while mitochondrial glycerol phosphate dehydrogenase activity is low ${ }^{(36)}$. These characteristics may explain why the coupling between glycolysis and mitochondrial glucose oxidation is not high in $\alpha$-cells. Recent reports, however, have shown that in pancreatic $\alpha$-cells labelled with yellow fluorescent protein, glucose hyperpolarises the mitochondrial membrane potential, further indicating that it directly affects mitochondrial metabolism and pointing to a $\mathrm{K}_{\mathrm{ATP}}$-dependent modulation of glucagon secretion by glucose ${ }^{(38)}$. In contrast, another recent study demonstrates that glucose acts directly on $\alpha$-cells to control glucagon release but through $\mathrm{K}_{\mathrm{ATP}}{ }^{-}$ independent mechanisms ${ }^{(39)}$. Additionally, the authors suggest that glucagon output may depend on the balance between the direct and indirect (paracrine) effects of glucose. In recent years, several molecules have been identified that may play a key role in the glucose-sensing capacity of $\alpha$-cells and its transduction into glucagon secretion. These include the per-arnt-sim domain-containing protein kinase (PASK) and AMP-activated protein kinase (AMPK), which are well-known energy sensors, as well as Rev-erb $\alpha$, a clock gene involved in metabolism ${ }^{(40-42)}$. Thus, a larger consensus is required regarding the role of $\alpha$-cell $\mathrm{K}_{\text {ATP }}$ channels and glucose metabolism in glucagon release. In addition to the role of glucose in glucagon secretion, it may also be involved in the regulation of $\alpha$-cell survival, although few studies have been made regarding this. It has been documented that high levels of glucose $(33.3 \mathrm{~mm})$ combined with palmitate to simulate in vitro glucolipotoxicity conditions induce apoptosis in pancreatic $\alpha$-cells ${ }^{(43)}$.

\section{Amino acids}

Although amino acids are important modulators of $\alpha$-cell secretion, little is known about this process at the molecular level and the mechanisms involved. Amino acids such as arginine, alanine and glutamine are potent stimulators of glucagon release, while leucine or lysine contribute to a lesser extent to $\alpha$-cell secretion ${ }^{(16,44-46)}$. It is postulated that the function of this increase in glucagon release is to physiologically prevent hypoglycaemia after protein intake, since amino acids also stimulate insulin secretion.
An increased glucagon secretion is observed if $\alpha$-cells are incubated in the presence of a mixture of different amino acids but not when exposed to each one of the nutrients separately ${ }^{(29,39,46)}$. In fact, the effect of glucose on intracellular $\mathrm{Ca}$ signalling and glucagon release is further detected in the presence of mediums containing a mixture of amino acids ${ }^{(39)}$, indicating that these nutrients are critical for $\alpha$-cell function. Ostenson \& Grebing ${ }^{(47)}$ showed that glutamine is a positive modulator of glucagon release. This effect involves the oxidation of this amino acid and is likely to be related to actions on glucose metabolism and ATP levels in the pancreatic $\alpha$-cell ${ }^{(47)}$. Moreover, a recent study performed in human islets from healthy and type 2 diabetic individuals showed that glycine, acting via an $\alpha$-cell-specific glycine receptor, was the predominant amino acid stimulating glucagon release via an intracellular $\mathrm{Ca}$ influx ${ }^{(48)}$. Similarly, ingested glycine increases plasma glucagon in human subjects ${ }^{(49)}$. Amino acids like arginine may be involved in the release of glucagon by direct plasma membrane depolarisation and $\mathrm{Ca}$ influx in the pancreatic $\alpha$-cell. However, other amino acids act as negative modulators. For instance, isoleucine can inhibit $\alpha$-cell secretion while leucine has a dual effect: it is a positive stimulus at physiological concentrations but becomes inhibitory at elevated levels ${ }^{(50)}$. In In-R1-G9 glucagonoma cells, concentrations of alanine and glutamine in the micromolar range contribute to the triggering of intracellular Ca oscillations, whereas these signals are inhibited with millimolar levels of these amino acids ${ }^{(51)}$. This effect has been attributed to amino acid-induced hyperpolarisation of the plasma membrane by the modulation of the $\mathrm{Na}-\mathrm{K}$ pump, and involves the intracellular metabolism of these nutrients. Therefore, divergent effects may take place depending on the type and concentration of amino acids.

\section{Fatty acids}

Even though lipotoxicity in pancreatic $\beta$-cells is one of the main factors related to obesity-induced diabetes, less is known about the role and potential toxic effect of fatty acids in the $\alpha$-cell. It has been shown that the modulation of glucagon release by fatty acids depends on the chain length, spatial configuration and degree of saturation of the fatty acid as well as the incubation time, which may lead to different acute or chronic effects ${ }^{(52-54)}$. The majority of studies show that short-term exposure to fatty acids stimulates glucagon release in isolated islets and clonal $\alpha$-cell lines ${ }^{(54,55)}$. Palmitate increases glucagon secretion by enhancing $\alpha$-cell intracellular $\mathrm{Ca}$ entry and also, by relieving the inhibitory paracrine action of somatostatin, which is secreted from $\delta$-cells ${ }^{(54)}$. Linoleic acid increases glucagon secretion in isolated mouse and rat islets as well as in In-R1-G9 glucagonoma cells ${ }^{(56,57)}$. This effect depends on the activation of the NEFA receptor G-protein coupled receptor 40 (GPR40) and the intracellular release of InsP3. Similar findings have been reported in rat islets with oleic acid ${ }^{(58)}$. The long-term 
effects of fatty acids have been examined alone or in the presence of high concentrations of glucose. When $\alpha$ TC1- 6 clonal $\alpha$-cells were cultured with palmitate and oleate for up to $3 \mathrm{~d}$, glucagon secretion was enhanced by means of fatty acid oxidation and TAG accumulation in a time- and dose-dependent manner but cell proliferation was decreased ${ }^{(59)}$. Accordingly, the long-term culture of this clonal $\alpha$-cell line with palmitate augmented glucagon release and enhanced glucagon expression and protein content, probably by activating the mitogenic mitogen-activated protein kinase (MAPK) pathway ${ }^{(60)}$. In contrast, it was observed that the inhibitory action of insulin on glucagon release was impaired in a long-term incubation with fatty acids. This was attributed to palmitate-induced insulin resistance due to defects in the insulin receptor substrate-1 (IRS-1)/phosphatidylinositol kinase (PI3K)/serine-threonine protein kinase (Akt) pathway ${ }^{(60)}$. In mouse isolated islets, long-term exposure to oleate and palmitate results in an over-secretion of glucagon at both low and high glucose concentrations but diminished glucagon protein content ${ }^{(52)}$. Similar results were observed in rat islets: the chronic effects of fatty acids produced a marked increase in glucagon release, but decreased glucagon content and did not change glucagon gene expression ${ }^{(44,61)}$. It has been recently reported that the survival of $\alpha$-cells, like of $\beta$-cells, is also sensitive to glucolipotoxic conditions: palmitate $(0.5 \mathrm{~mm})$ combined with high glucose levels are able to induce apoptosis in rodent $\alpha$-cells ${ }^{(43)}$. In general, all these data support the hypothesis that chronic elevation of fatty acids might contribute to $\alpha$-cell deregulation in type 2 diabetes.

\section{Other nutrients}

$\alpha$-Cell function is also sensitive to vitamins. For instance, plasma glucagon levels and glucagon release have been found to be augmented in rats with a diet deficiency of vitamin $\mathrm{D}_{3}^{(62)}$ while no major effects have been reported in non-insulin-dependent diabetic patients supplemented with vitamin $\mathrm{D}^{(63)}$. Glucagon secretion is markedly impaired in rats subjected to vitamin A dietary deficiencies ${ }^{(64)}$. Additionally, retinol- and retinoic acid-binding proteins have been detected in glucagon-secreting $\alpha$-cell lines while retinol and retinoic acid have been demonstrated to inhibit glucagon secretion in cultured rat islets ${ }^{(64,65)}$. Important increases in plasma glucagon levels are also related to biotin deficiencies due to fasting ${ }^{(66)}$.

\section{Other levels of regulation}

In addition to nutrients, pancreatic $\alpha$-cells are subjected to other control levels. These include neural regulation as well as autocrine, paracrine and endocrine signalling pathways that interact with the different steps involved in glucagon release or synthesis ${ }^{(9)}$. Although numerous neurotransmitters released by nerve endings situated within the islet are associated with a stimulatory effect on glucagon secretion, the molecular and cellular mechanisms are still not well understood ${ }^{(7)}$. Parasympathetic neurotransmitters such as vasoactive intestinal polypeptide, gastrinreleasing peptide, pituitary adenylate cyclase-activating polypeptide and acetylcholine have a stimulatory effect on pancreatic $\alpha$-cells ${ }^{(67,68)}$. Similarly, sympathetic nerves within the islet have a glucagonotropic effect via neurotransmitters such as noradrenaline, galanin and neuropeptide $\mathrm{Y}^{(7,69)}$. Sympathetic activation can also induce adrenaline release, which is a potent stimulator of pancreatic $\alpha$-cell exocytosis $^{(70)}$. Sensory nerves containing calcitonin generelated protein and substance $\mathrm{P}$ may also trigger glucagon release from the pancreatic islet ${ }^{(7)}$. It has been also shown that $\alpha$-cells can secrete neural factors such as acetylcholine or glutamate ${ }^{(71,72)}$. Neural regulation of islet function has been related to the control of the pulsatile release of islet hormones and the synchronisation of individual cell responses within the islet ${ }^{(9)}$. Additionally, neural regulation allows for a further control of the glucagon secretory response to hypoglycaemia as well as the suppression of glucagon secretion in conditions of hyperglycaemia ${ }^{(9,15)}$. This neural control is mediated by glucose-sensing neurons located in the ventromedial hypothalamus ${ }^{(73)}$.

Additionally, islet hormones such as insulin, glucagon and somatostatin or $\beta$-cell-secretory products such as ATP, $\gamma$-aminobutyric acid, amylin or $\mathrm{Zn}$ also act as paracrine and autocrine signals that affect $\alpha$-cell physiology $^{(9,74,75)}$. Extrapancreatic hormones such as leptin and gastrointestinal incretins can also modulate $\alpha$-cell function $^{(22,76)}$. In this latter group of hormones, glucagon-like peptide-1 (GLP-1) is one of the most important bioactive peptides with numerous islet effects. GLP-1 is produced by intestinal ileum L-cells by post-translational processing of proglucagon and is secreted after a meal in response to nutrients ${ }^{(22,76)}$. Given that GLP-1 has a potent glucoseinduced insulinotropic action but reduces glucagon release, some pharmacological approaches in diabetes have led to the design of GLP-1 derivatives of improved duration and resistance to degradation compared with the natural hormone ${ }^{(22,76)}$. In contrast to the suppressive effect on glucagon release observed in animal models and human subjects ${ }^{(77)}$, initial experiments at the cellular level reported an enhanced protein kinase A (PKA)dependent exocytosis in rat pancreatic $\alpha$-cells, which was associated with increased glucagon secretion ${ }^{(78)}$. In light of these findings, it was proposed that the GLP-1 inhibitory effect on pancreatic $\alpha$-cells may rely on paracrine mechanisms ${ }^{(78,79)}$. However, recent studies in mice have shown that GLP-1 can indeed reduce glucagon secretion in $\alpha$ cells by PKA-dependent inhibition of a specific subset of Ca channels via a small increase in intracellular cyclic AMP (cAMP) concentrations ${ }^{(70)}$. These last observations support a molecular basis for the studies showing an inhibitory GLP-1 action on glucagon release. Unlike GLP-1, a stimulatory effect has been reported for the gastrointestinal hormone glucose-dependent insulinotropic 
polypeptide (GIP), which is produced by intestinal K-cells. Studies with perifused mouse pancreatic islets showed that GIP was able to reverse the suppressive effect of high glucose levels on glucagon release ${ }^{(80)}$. In primary rat $\alpha$-cells and perfused rat pancreas, GIP stimulated glucagon release at low glucose concentrations ${ }^{(79)}$.

\section{Actions of glucagon on nutrient metabolism}

\section{Glucagon synthesis}

The preproglucagon gene is mainly expressed in pancreatic $\alpha$-cells, in intestinal L-cells and in the central nervous system and is closely regulated by nutritional status. The preproglucagon promoter contains up to six regulatory sequences called G1-5 and CRE (cAMP response element), which confers responsiveness to cAMP. The promoter consists of a region comprising the regulatory sequences $\mathrm{G} 1$ and $\mathrm{G} 4$ while the remaining sequences are part of the enhancer regions. Numerous transcription factors are involved in the control of glucagon expression such as LIM-homeobox transcription factor islet-1 (Isl1), paired box gene 6 (Pax6), musculoaponeurotic fibrosarcoma oncogene homolog (Mafs), forkhead box protein A1 (Foxa1) and forkhead box protein A2 (Foxa2) among others $^{(81,82)}$. The transcription of the preproglucagon gene results in a peptide of 160 amino acids. The processing of this peptide into glucagon, GLP-1 and GLP2 hormones depends on the post-translational cleavage mediated by different prohormone convertase (PC) subtypes. The differential cell-specific expression of PC generates different peptides in each tissue ${ }^{(83)}$. PC2 is responsible in $\alpha$-cells for the production of glucagon in addition to other products such as glicentin, glicentin-related pancreatic polypeptide, intervening peptide 1 and the major proglucagon fragment ${ }^{(84-86)}$. The importance of PC2 for the correct processing of glucagon has been proven in experiments using $\mathrm{PC} 2$ knockout $(\mathrm{KO})$ mice $^{(87)}$. In contrast to the results in some clonal $\alpha$-cell lines ${ }^{(88,89)}$, studies in isolated rat islets indicate that the effect of glucose on glucagon gene expression is not direct but occurs via paracrine mechanisms that stimulate the inhibitory insulin signal ${ }^{(44)}$. This hormone decreases glucagon gene expression in pancreatic $\alpha$-cells by activating phosphatidylinositol kinase (PI3K) and PKB pathways ${ }^{(90-92)}$. In line with these findings, the enhanced glucagon expression found in rats with insulinopenic diabetes was corrected by administrating insulin ${ }^{(88)}$. As mentioned earlier, it has been reported that lipids are able to modulate glucagon gene expression both in a paracrine way through their effects on $\beta$-cells ${ }^{(60)}$ and by direct mechanisms ${ }^{(55)}$. In the latter case, while short-term experiments indicate a down-regulation of the glucagon gene after being treated with palmitate ${ }^{(55)}$, no effect has been observed in long-term studies ${ }^{(44,61)}$. Amino acids may also play a role in glucagon gene regulation, although much further investigation is still necessary: while arginine has been shown in some studies to increase glucagon expression and protein synthesis via protein kinase $\mathrm{C}$ activation ${ }^{(93)}$, other researchers have failed to observe these changes ${ }^{(44)}$. In clonal $\alpha$ TC1-6 cells, the removal of histidine from the culture leads to a decrease in preproglucagon gene expression similar to what is observed in an amino acid-free medium ${ }^{(94)}$

\section{Glucagon receptor and intracellular signalling}

The glucagon receptor is a protein belonging to the secretin-glucagon receptor II class family of the G protein-coupled receptors and consists of 477 amino acids in humans and 485 amino acids in rodents with a primary sequence homology of more than $80 \%$ between them ${ }^{(95)}$. This receptor is characterised by seven transmembrane-spanning domains connected by three intracellular and extracellular loops. Its activation is coupled to GTPbinding heterotrimeric $G$ proteins of the Gas type that stimulate adenylate cyclase and PKA ${ }^{(96)}$. Although glucagon-induced PKA signalling is the most important biochemical cascade, this hormone can also activate the phospholipase $\mathrm{C} /$ inositol phosphate pathway via $\mathrm{G}_{\mathrm{q}}$ proteins, resulting in the release of $\mathrm{Ca}^{2+}$ from intracellular stores $^{(95)}$. In addition, glucagon has also been implicated in signalling via $5^{\prime}-\mathrm{AMPK}^{(13,97)}$, p38 MAPK and c-Jun N-terminal kinase $(\mathrm{JNK})^{(13,98)}$ (Fig. 2). Although the glucagon receptor is mainly expressed in the liver, its expression is also observed in multiple tissues including the pancreas, heart, kidney, brain, smooth muscle, adipocytes, lymphoblast, spleen, retina, adrenal gland and gastrointestinal tract $^{(99)}$. Although a preferential expression of the glucagon receptor is found in pancreatic $\beta$-cells, it is also expressed, to a lesser degree, in non- $\beta$-cells, including glucagonsecreting $\alpha$-cells ${ }^{(100,101)}$. Mice lacking the glucagon receptor exhibit several phenotypic alterations such as pancreatic $\alpha$-cell hyperplasia, hyperglucagonaemia, mild hypoglycaemia, increased number of islets per pancreas and increased GLP-1 plasma levels ${ }^{(102)}$. Additionally, these mice show resistance to high-fat diet-induced hyperinsulinaemia and streptozotocin-induced diabetes, while exhibit improved insulin sensitivity compared with wildtype controls ${ }^{(103-106)}$. However, a specific over-expression of the glucagon receptor in pancreatic $\beta$-cells also improves glucose tolerance in mice exposed to high-fat diets, suggesting an improvement in $\beta$-cell function ${ }^{(107)}$.

\section{Effects of glucagon on hepatic nutrient metabolism}

The primary target organ of glucagon is the liver where the insulin:glucagon ratio controls multiple key steps of hepatic metabolism (Fig. 2). The action of glucagon on the liver plays a key role in glucose homeostasis, particularly in adaptive and counter-regulatory responses to hypoglycaemic conditions, fasting and starvation ${ }^{(13)}$ as well as in situations of increased fuel demand such as vigorous 


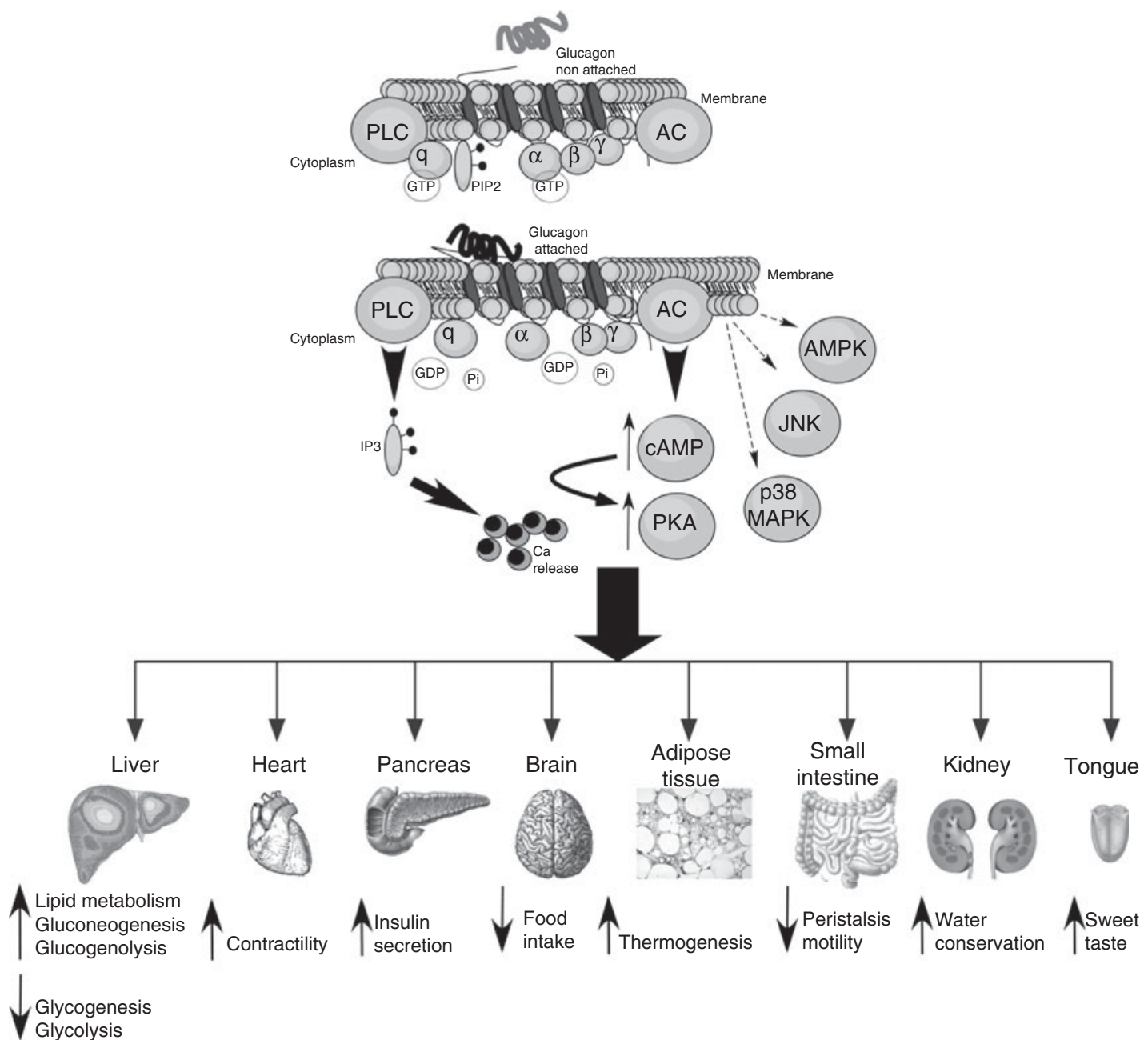

Fig. 2. Glucagon intracellular signalling and actions in different tissues. Intracellular signalling and biochemical pathways activated by glucagon are illustrated in the top of the figure. The different target tissues of glucagon as well as its effects are summarised in the lower part of the figure. For further information, see the text. PLC, phospholipase c; PIP2, phosphatidylinositol 4,5-bisphosphate; AC, adenylate cyclase; Pi, inorganic phosphate; IP3, inositol 1,4,5-trisphosphate; AMPK, AMP-activated protein kinase; JNK, c-Jun N-terminal kinase; cAMP, cyclic AMP; PKA, protein kinase A; MAPK, mitogen-activated protein kinase.

exercise $^{(108)}$ or states of metabolic stress such as trauma, inflammation or sepsis ${ }^{(109)}$. Given that the brain relies on a continuous glucose supply, several lines of defence against hypoglycaemia take place to counterbalance this situation. These include glucose-sensitive neural responses, an increased release of hyperglycaemic hormones such as adrenaline and an enhanced glucagon secretion. Additionally, glucagon opposes numerous insulin actions. Glucagon has a dual effect on the liver: on the one hand, it stimulates gluconeogenesis and glycogenolysis increasing hepatic glucose output and, on the other hand, it decreases glycogenesis and glycolysis ${ }^{(9,110)}$. These effects along with decreased plasma insulin levels allow for the restoration of normoglycaemia by favouring hepatic glucose release. Although the glucagon receptor is highly selective for glucagon, it can also bind to other glucagon-related peptides $^{(111)}$. One of the main effects of glucagon to modulate gluconeogenesis is the up-regulation of key enzymes involved in this process such as glucose-6-phosphatase and phosphoenolpyruvate carboxykinase through the activation of the cAMP response element-binding protein and PPAR $\gamma$-coactivator- $1^{(110,112)}$. The modulatory effect of glucagon on pyruvate kinase accounts for the down-regulation of glycolysis ${ }^{(9)}$. Glucagon also regulates glycogen synthesis and lysis by modulating the activity of glycogen synthase and glycogen phosphorylase via the phosphorylation of these enzymes ${ }^{(113)}$.

Glucagon is not only implicated in glucose homeostasis but in hepatic lipid metabolism as well. Several reports indicate that TAG production is decreased in perfused livers treated with glucagon ${ }^{(114,115)}$. The potential hypolipidaemic actions of glucagon after its administration also include a reduction in plasma and hepatic TAG, decreased VLDL and cholesterol levels, as well as increased fatty acid oxidation $^{(13,14,116,117)}$. Moreover, reduced glucagon signalling has been related to the development of fatty liver ${ }^{(118)}$. Experiments using $\mathrm{KO}$ and wild-type mice for the glucagon receptor showed that administering glucagon 
not only reduces the synthesis and secretion of TAG and their plasma levels but also stimulates fatty acid oxidation $^{(13)}$. These effects depend on the activation of PPAR $\alpha$ and are necessary for the adaptive metabolic response to fasting. In line with these results, these $\mathrm{KO}$ mice rapidly develop hepatosteatosis compared with wildtype controls when exposed to a high-fat diet ${ }^{(13)}$. This finding in glucagon receptor $\mathrm{KO}$ mice contrasts with the resistance to hepatosteatosis found in this model by others ${ }^{(103)}$. In diet-induced hepatic steatosis, glucagon signalling may be impaired as a consequence of a reduced number of hepatic plasma membrane glucagon receptors $^{(119)}$. Recently, it has been demonstrated in $\mathrm{db} / \mathrm{db}$ mice that the inhibition of hepatic glucagon signalling leads to an increase in LDL due to an over-expression of hepatic lipogenic genes and elevated de novo lipid synthesis ${ }^{(120)}$. In addition to lipid metabolism, glucagon can also stimulate the hepatic uptake of amino acids. Accordingly, hyperglucagonaemia may be related to plasma hypoaminoacidaemia, particularly with those amino acids involved in gluconeogenesis, such as alanine, glycine and proline ${ }^{(121)}$.

\section{Effects of glucagon on food intake, body weight and body energy}

Glucagon is able to exert several actions on food intake behaviour as well as on the regulation of weight and body energy (Fig. 2). However, the precise signalling mechanisms that allow this hormone to perform these actions are still unclear. It has been shown that glucagon receptors are present in the rat brain, including the hypothalamus ${ }^{(122)}$, and that glucagon is able to bind to mouse astrocyte suspensions and induce cAMP production ${ }^{(123)}$. Additionally, this hormone is able to suppress the electrical activity of glucose-sensitive hypothalamic neurons ${ }^{(124)}$. Intraventricular infusion of glucagon leads to hyperglycaemia ${ }^{(125)}$ but it also decreases food intake, an effect that is less potent when glucagon is administered peripherally $^{(124)}$. In addition to a potential direct action on central regions, it has been reported that glucagon may be sensed by peripheral vagal nerves that communicate the signal to satiety control areas of the hypothalamus to exert an anorexigenic action. This is supported by experiments in which a glucagon-induced decrease in food intake was suppressed when animals were subjected to hepatic vagotomy ${ }^{(126)}$. This reduced food intake when glucagon is infused has been observed not only in rodents but in human subjects as well ${ }^{(127-129)}$. The anorectic action of glucagon has been related to its ability to reduce meal size ${ }^{(130)}$, an effect that can be abolished with the infusion of neutralising glucagon antibodies ${ }^{(131)}$. Severe anorexia is also found in rats when transplanted with glucagonomas, further supporting the satiating role of this hormone ${ }^{(132)}$. In contrast with these findings, glucagon receptor $\mathrm{KO}$ mice fed with high-fat diets exhibit lower food intake and body-weight increase than wild-type controls ${ }^{(103)}$.
In addition to the central actions mentioned above, it has been suggested that the satiety effect of glucagon may involve the suppression of the orexigenic hormone ghrelin via the hypothalamic-pituitary axis ${ }^{(133)}$. It has recently been reported that hypothalamic glucagon signalling inhibits hepatic glucose production and that the central resistance to this hormone might be involved in the hyperglycaemia that characterises diabetes ${ }^{(134)}$.

Considerable evidence supports the role of glucagon as a thermogenic agent, thereby favouring the body's energy expenditure. In rats, an energy-increasing effect of glucagon was reported some time ago ${ }^{(135)}$. In healthy volunteers, RMR increases after glucagon infusion in conditions of insulin deficiency ${ }^{(136)}$. The presence of insulin seems to counterbalance this glucagon action ${ }^{(137)}$. Recently, indirect calorimetry measurements in obese, non-diabetic individuals showed that glucagon infusion alone or in combination with GLP-1 is able to increase resting energy expenditure $^{(138)}$. These thermogenic effects have been associated with direct actions on brown adipose tissue due to increased oxygen consumption, metabolism and heat production in both in vitro and in vivo experiments $^{(139-141)}$. Additionally, chronic glucagon administration in rats increases the mass of brown adipose tissue as well as its thermogenic capacity and fatty acid uptake ${ }^{(142)}$. Several reports suggest that these effects are mediated by the sympathetic nervous system via catecholamines $^{(143)}$. This is supported by experiments in which the glucagon effect is prevented or reduced in conditions of brown adipose tissue denervation or pharmacological $\beta$-adrenergic inhibition with propranolol ${ }^{(142,144)}$. It has also been shown that glucagon reduces body weight in both humans and normal rats ${ }^{(139,145)}$ as well as in obese Zucker rats ${ }^{(146)}$, a model of genetic obesity. These effects may probably be due to the above-mentioned glucagon action on food intake and energy expenditure. Recent results in mice confirm that glucagon not only induces a loss of body weight and fat mass but also lowers plasma cholesterol levels ${ }^{(147)}$. All these processes are attributed to the enhanced secretion of fibroblast growth factor 21 (FGF21) in plasma, whose levels are increased when glucagon is infused in mice and human subjects. Thus, glucagon may have potential therapeutic implications not only for diabetes but also for obesity.

\section{Other effects of glucagon}

Although the effect of glucagon on the liver is the best known, this hormone also affects other extra-hepatic organs and tissues (Fig. 2). Glucagon-receptor KO mice exhibit $\alpha$-cell hyperplasia ${ }^{(102)}$, which is consistent with in vitro experiments showing that glucagon downregulates $\alpha$-cell proliferation in an autocrine manner ${ }^{(148)}$. The secretion of this hormone also increases in mouse and rat pancreatic $\alpha$-cells via cAMP production ${ }^{(76)}$. The over-expression of the glucagon receptor in pancreatic 
$\beta$-cells improves glucagon- and glucose-stimulated insulin secretion, and enhances $\beta$-cell mass as well as glucose tolerance ${ }^{(107)}$. The direct effect of glucagon on $\beta$-cells is further supported by experiments showing that this hormone increases insulin release in perfused pancreas and isolated $\beta$-cells ${ }^{(101,149)}$. Additionally, glucagon produces cardiac ionotropic and chronotropic actions, partly by stimulating Ca currents via cAMP production and the inhibition of phosphodiestarases ${ }^{(150)}$, thus leading to increased contractility ${ }^{(151)}$. It has also been indicated that this hormone regulates cardiac metabolism at the level of glucose utilisation $^{(152)}$. The role of glucagon in adipose tissue has been controversial for a long time. Glucagon has been reported to augment lipolysis in isolated rodent and human adipocytes ${ }^{(153,154)}$. The physiological meaning of these results has been disputed based on findings that show no effect of glucagon on the abdominal fat tissue of healthy individuals submitted to microdialysis ${ }^{(155)}$. However, new studies have reported glucagon-induced lipolysis in healthy volunteers, diabetic patients, diabetic animal models and isolated adipocytes from these animals ${ }^{(11)}$. All these effects were attributed to a glucagon-induced release of FGF21, which has lipolytic activity. Actually, recent reports demonstrate that FGF21 also mediates other different glucagon actions, as we previously commented $^{(147)}$. Given that the lipolytic action of glucagon is blunted in denervated rats, its effect on adipose tissue has also been associated with sympathetic signals ${ }^{(156)}$. Kidneys are also a target site for glucagon, since its intravenous infusion is related to changes produced in urea synthesis and excretion as well as in water conservation $^{(157)}$. In in vitro perfused inner medullary collecting ducts, glucagon induces cAMP production and changes in aquaporin 2 expression that affect water excretion $^{(158)}$. Glucagon is also used as an anti-peristaltic agent because of its effects on small intestine motility $^{(159,160)}$. Moreover, it has recently been reported that glucagon also enhances sweet taste responses by acting directly on the mouse gustatory epithelium ${ }^{(161)}$.

\section{Involvement of glucagon in diabetes pathophysiology}

Role of glucagon in the control of glycaemia during diabetes mellitus

Type 1 diabetes is characterised by an autoimmune specific $\beta$-cell loss that results in insulin deficiency, leading to hyperglycaemia. These high plasma glucose levels are filtered by kidneys, which may result in glycosuria and, eventually, osmolar alterations that can produce a nonketotic hyperosmolar coma. Since glucose utilisation as an energy substrate is limited as a consequence of insulin deficiency, increased levels of fatty acids are oxidised to acetyl CoA, increasing the production of ketonic bodies and ketonuria with the concomitant risk of ketoacidosis. Other symptoms that develop in poorly controlled diabetes are polyuria, polydipsia and polyphagia. Since the basic treatment for diabetes is insulin administration, another major complication may be hypoglycaemia (iatrogenic hypoglycaemia), which results from an excess of insulin in a condition of impaired homeostatic responses against the decline in plasma glucose levels ${ }^{(15)}$. In the case of type 2 diabetes, hyperglycaemia is due to a combination of increased peripheral resistance to the action of insulin along with inappropriate insulin secretion. This situation can eventually progress to $\beta$-cell death ${ }^{(9)}$, thus leading to a greater deterioration of glucose homeostasis and a worsening of hyperglycaemia. This type of diabetes is often associated with obesity. In both types of diabetes, poorly controlled glycaemia can lead to micro- and macrovascular, neural, retinal and renal complications as well as skin ulcers and, eventually, amputation.

In addition to the central role of insulin and pancreatic $\beta$-cells in the pathophysiology of diabetes, abundant evidence demonstrates that glucagon is also involved in this metabolic disorder. Absolute or relative (to insulin) hyperglucagonaemia is frequently found in diabetes during fasting and postprandial periods ${ }^{(162-164)}$. Hyperglucagonaemia in the context of insufficient insulin secretion and/or insulin resistance is associated with increased hepatic glucose output, which contributes to hyperglycaemia ${ }^{(48,165)}$. Additionally, $\alpha$-cell function in response to changes in glucose is impaired in diabetes ${ }^{(166)}$. For instance, hyperglycaemia fails to suppress glucagon secretion in diabetic patients, which further exacerbates their high glucose levels during postprandial periods ${ }^{(167,168)}$. Although the mechanism for this failure is not clearly known, it has been suggested that the $\alpha$-cell might be refractory to the insulin paracrine signal or insensitive to high glucose levels ${ }^{(9,15)}$. Patients with a glucagonoma develop hyperglucagonaemia and the characteristic hyperglycaemia of diabetes, which disappears when the tumour is removed, further suggesting that high levels of glucagon are involved in this disease ${ }^{(169)}$. Another problem of diabetes is that pancreatic $\alpha$-cells do not respond adequately to hypoglycaemia, which is particularly important in insulin-treated patients, and leads to increased morbidity and mortality rates in this disease ${ }^{(8,23)}$. This life-threatening situation seems to be the result of several altered processes: impaired $\alpha$-cell sensing of falling glucose levels, an inefficient effect of the withdrawal of the insulin inhibitory signal during hypoglycaemia as well as a defective function of the autonomous nervous system and of the different defence mechanisms against hypoglycaemia ${ }^{(8,170-172)}$. In addition to an altered $\alpha$-cell function, diabetes has been also associated with increases in either absolute or relative (to $\beta$-cells) $\alpha$-cell mass in animal models and humans ${ }^{(173-175)}$, which may explain the higher plasma glucagon levels in these patients.

Glucagon is also involved in protein and fat metabolic alterations in diabetes. This hormone plays a catabolic role during a protein load ${ }^{(176)}$ and hyperglucagonaemia 
induces phenylalanine oxidation in healthy humans ${ }^{(177)}$. Individuals with a glucagonoma exhibit higher levels of free amino acids in muscles and the liver ${ }^{(178)}$. In type 1 diabetic patients, hyperglucagonaemia has been related to different catabolic effects including an increased RMR and increased leucine oxidation, effects that were independent of insulin deficiency ${ }^{(179)}$. Because of the effect of this hormone on amino acid hepatic uptake and the stimulation of gluconeogenesis, hyperglucagonaemia can lead to marked hypoaminoacidaemia, particularly from those amino acids that participate in gluconeogenesis ${ }^{(121,180)}$. Glucagon has also been involved in lipid metabolism. Although the role of glucagon in adipose tissue lipolysis has remained controversial for a long time, new evidence in animal models and human subjects, including diabetic patients, demonstrates this effect ${ }^{(11)}$. These actions may be the result of the activation of hormone-sensitive lipase $^{(181)}$ and probably involve the participation of FGF21 ${ }^{(11)}$. In animal models, chronic administration of glucagon induces hypolipidaemic effects ${ }^{(182,183)}$. Furthermore, it has been recently shown that hyperglucagonaemia modulates hepatic lipoprotein particle metabolism in humans both by decreasing hepatic lipoprotein particle production and by inhibiting particle clearance ${ }^{(14)}$. In the context of insulin deficiency and high levels of fatty acids, glucagon can accelerate the formation of ketonic bodies from the liver ${ }^{(184-186)}$. Consistent with this, it has been observed that diabetic ketoacidosis is associated with hyperglucagonaemia combined with hypoinsulinae$\mathrm{mia}^{(187,188)}$. Thus, in view of the role that glucagon plays in the pathophysiology of diabetes, it would be advisable to develop therapeutic strategies to limit either glucagon secretion or action.

\section{Therapeutic potential of modulating glucagon secretion} and action in diabetes

Numerous studies have shown that restrained glucagon action is beneficial for the control of hyperglycaemia and/or diabetes management. For instance, glucagonreceptor KO mice exhibit reduced fasting hypoglycaemia and improved glucose tolerance ${ }^{(102)}$. Additionally, these mice are resistant to diet-induced obesity, as well as streptozotocin-induced $\beta$-cell loss and hyperglycaemia ${ }^{(103)}$. Similarly, lower hepatic glucose production and improved glucose tolerance are observed in mice that are deficient in the $\alpha$-cell transcription factor ARX (aristaless-related homeobox), leading to the loss of glucagon-producing $\alpha$-cells ${ }^{(189)}$. More recently, it has been shown that the metabolic and clinical alterations caused by type 1 diabetes are absent in glucagon receptor KO mice treated with streptozotocin and that the restoration of the hepatic glucagon receptor in this model leads to the reappearance of hyperglycaemia ${ }^{(104,190)}$. However, a limited glucagon action could interfere with the role of glucagon in hepatic lipid metabolism and lead to an increased susceptibility to hepatosteatosis after a high-fat diet ${ }^{(13)}$, or it could also interfere with the hepatic survival function of glucagon ${ }^{(191)}$. Additionally, in this kind of KO mice the exocrine and endocrine cell masses are augmented, increasing the risk of developing tumours ${ }^{(102)}$. Thus, all these aspects require further examination in human subjects. Consistent with these findings in $\mathrm{KO}$ mice, other strategies such as glucagon antibodies, glucagon receptor antisense oligonucleotides and glucagon receptor antagonists revealed similar findings in hepatic glucose production and showed an antihyperglycaemic effect in diabetic animal models as well as in a few human studies ${ }^{(9,192-195)}$. The antagonism of glucagon action on the liver also partly mediates the glucose-lowering effect of biguanides ${ }^{(196)}$. It has been recently demonstrated that the design of peptides with dual agonism for both the glucagon and the GLP-1 receptors is useful to fight against obesity in mice without any apparent adverse effects ${ }^{(197,198)}$. This is mainly the result of the antihyperglycaemic, lipolytic, satiating and energy expenditure actions of this combined treatment. In human subjects, the co-administration of GLP-1 during glucagon infusion leads to increased resting energy expenditure and lower hyperglycaemia ${ }^{(138)}$. In the present study, the augmented energy expenditure was attributed to glucagon alone. Similarly, chronic glucagon receptor agonism in dietinduced obese mice lowered food intake, body weight, fat mass and cholesterolaemia while increasing energy expenditure ${ }^{(147)}$. The actions of glucagon were mediated by FGF21. This growth factor has also been involved in the lipolytic action of glucagon in diabetic and non-diabetic animals and humans ${ }^{(11)}$. Additionally, peripherally administered glucagon inhibits food intake, presumably by the neural activation of appetite-regulating brain centres ${ }^{(199)}$. Thus, the combined activation of glucagon and GLP-1 receptors has been proved to be useful for the design of strategies against obesity and diabetes.

The modulation of glucagon secretion with a therapeutic potential has also been explored. Exogenous GLP-1 administration is known to stimulate insulin release while inhibiting glucagon secretion in isolated rodent islets, in perfused rat pancreas and in human subjects, which allows for the improvement of hyperglycaemia ${ }^{(9,200)}$. The effect on glucagon is mediated by the direct action on pancreatic $\alpha$-cells ${ }^{(70)}$. Accordingly, GLP-1 agonists widely used in diabetes treatment such as exenatide or liraglutide also exert hypoglycaemic effects by lowering plasma glucagon levels ${ }^{(201)}$. Similar actions have been reported for inhibitors of the GLP-1-degrading enzyme dipeptidyl peptidase 4 (DPP-4) ${ }^{(202)}$. DPP-4 inhibitors commonly used in diabetes such as vildagliptin or sitagliptin suppress hepatic glucose production by augmenting insulin release and lowering glucagon secretion ${ }^{(203)}$. Other drugs such as pramlintide, a synthetic analogue of islet amyloid polypeptide, also decreases glucagon secretion after a meal in diabetic individuals and may act on reducing hepatic glucose output to improve hyperglycaemia ${ }^{(202,204)}$. 


\section{Conclusions and future directions}

The hyperglycaemic hormone glucagon has a key role in the control of glucose homeostasis by acting on the liver to stimulate gluconeogenesis and glycogenolysis and inducing hepatic glucose release. This hormone opposes the actions of insulin and is one of the main lines of defence against hypoglycaemic episodes, fasting and starvation, maintaining normoglycaemia. Less information is available about the function of glucagon during exercising or situations of metabolic stress. Although the main signalling pathway related to glucagon is mediated primarily by the activation of adenylate cyclase/PKA and, secondarily by phospholipase C/inositol 1,4,5-trisphosphate, recent studies have shown that AMPK, p38 MAPK and c-Jun N-terminal kinase (JNK) are also signalling conduits for glucagon. It would, therefore, be interesting to explore other potential signalling routes. In addition to the wellknown effect of glucagon on hepatic glucose, this hormone also contributes to the regulation of lipid metabolism in the liver. Moreover, although glucagon receptors are present in numerous tissues including the heart, adipose tissue, kidneys and the brain among others, the effects and molecular pathways involved still require further examination, particularly those that glucagon produces at the central level. Despite the importance of pancreatic $\alpha$-cells in the secretion of glucagon, the understanding of their regulation at molecular and cellular levels has been scarce for a long time. However, research on these cells and their role in nutrient metabolism and body energy has experienced a renewed impetus in recent years. It has been demonstrated that alterations in pancreatic $\alpha$-cell function and glucagon actions are part of the pathophysiological events related to the development of diabetes. In this regard, several experimental approaches to improve diabetic symptoms include the modulation of glucagon release or its actions. Additionally, glucagon alone or in combination with other hormones may be relevant in the control of appetite, body weight and the treatment of obesity. Accordingly, this renewed interest in the pancreatic $\alpha$-cell and glucagon may reveal new therapeutic strategies for metabolic disorders such as obesity and diabetes.

\section{Acknowledgements}

The authors acknowledge the work of current and former researchers of the authors' laboratory for their experimental support. CIBER de Diabetes y Enfermedades Metabólicas Asociadas (CIBERDEM) is an initiative of the Instituto de Salud Carlos III.

The present review was supported by grants from the Ministerio de Ciencia e Innovación (no. BFU2010-21773 and BFU2011-28358), Generalitat Valenciana (no. PROMETEO/2011/080 and ACOMP/2013/022) and the European Foundation for the Study of Diabetes (EFSD/BI Basic
Programme). Funders had no role in the design, analysis or writing of the present review.

L. M. and I. Q. wrote the manuscript. B. M. designed the figures. L. M., P. A.-M., B. M., E. F., A. N. and I. Q. contributed to the discussion and revision of the text and approved the final manuscript.

There are no conflicts of interest to declare.

\section{References}

1. Brissova M, Fowler MJ, Nicholson WE, et al. (2005) Assessment of human pancreatic islet architecture and composition by laser scanning confocal microscopy. J Histochem Cytochem 53, 1087-1097.

2. Cabrera O, Berman DM, Kenyon NS, et al. (2006) The unique cytoarchitecture of human pancreatic islets has implications for islet cell function. Proc Natl Acad Sci US A 103, 2334-2339.

3. Nadal A, Quesada I \& Soria B (1999) Homologous and heterologous asynchronicity between identified $\alpha-, \beta$ - and $\delta$-cells within intact islets of Langerhans in the mouse. J Pbysiol 517, 85-93.

4. Quesada I, Todorova MG \& Soria B (2006) Different metabolic responses in $\alpha-, \beta$-, and $\delta$-cells of the islet of Langerhans monitored by redox confocal microscopy. Biophys J 90, 2641-2650.

5. Smith FE, Rosen KM, Villa-Komaroff L, et al. (1991) Enhanced insulin-like growth factor I gene expression in regenerating rat pancreas. Proc Natl Acad Sci U $A \mathbf{8 8}$, 6152-6156.

6. Unger RH \& Orci L (2010) Paracrinology of islets and the paracrinopathy of diabetes. Proc Natl Acad Sci US A $\mathbf{1 0 7}$, 16009-16012.

7. Ahren B (2000) Autonomic regulation of islet hormone secretion - implications for health and disease. Diabetologia 43, 393-410.

8. Taborsky GJ Jr \& Mundinger TO (2012) Minireview: the role of the autonomic nervous system in mediating the glucagon response to hypoglycemia. Endocrinology 153, 1055-1062.

9. Quesada I, Tuduri E, Ripoll C, et al. (2008) Physiology of the pancreatic $\alpha$-cell and glucagon secretion: role in glucose homeostasis and diabetes. J Endocrinol 199, 5-19.

10. Unger RH, Aguilar-Parada E, Muller WA, et al. (1970) Studies of pancreatic $\alpha$ cell function in normal and diabetic subjects. J Clin Invest 49, 837-848.

11. Arafat AM, Kaczmarek P, Skrzypski M, et al. (2013) Glucagon increases circulating fibroblast growth factor 21 independently of endogenous insulin levels: a novel mechanism of glucagon-stimulated lipolysis? Diabetologia 56, 588-597.

12. Bertin E, Arner P, Bolinder J, et al. (2001) Action of glucagon and glucagon-like peptide-1-(7-36) amide on lipolysis in human subcutaneous adipose tissue and skeletal muscle in vivo. J Clin Endocrinol Metab 86, 1229-1234.

13. Longuet C, Sinclair EM, Maida A, et al. (2008) The glucagon receptor is required for the adaptive metabolic response to fasting. Cell Metab 8, 359-371.

14. Xiao C, Pavlic M, Szeto L, et al. (2011) Effects of acute hyperglucagonemia on hepatic and intestinal lipoprotein production and clearance in healthy humans. Diabetes $\mathbf{6 0}$ 383-390.

15. Cryer PE (2012) Minireview: glucagon in the pathogenesis of hypoglycemia and hyperglycemia in diabetes. Endocrinology 153, 1039-1048. 
16. Gerich JE, Lorenzi M, Schneider V, et al. (1974) Effect of somatostatin on plasma glucose and insulin responses to glucagon and tolbutamide in man. J Clin Endocrinol Metab 39, 1057-1060.

17. Ohneda A, Aguilar-Parada E, Eisentraut AM, et al. (1969) Control of pancreatic glucagon secretion by glucose Diabetes 18, 1-10.

18. Salehi A \& Vieira E (2006) Gylfe E Paradoxical stimulation of glucagon secretion by high glucose concentrations. Diabetes 55, 2318-2323.

19. Vieira E \& Salehi A (2007) Gylfe E Glucose inhibits glucagon secretion by a direct effect on mouse pancreatic $\alpha$ cells. Diabetologia 50, 370-379.

20. Gopel S, Zhang Q, Eliasson L, et al. (2004) Capacitance measurements of exocytosis in mouse pancreatic $\alpha-, \beta$ and $\delta$-cells within intact islets of Langerhans. $J$ Physiol 556, 711-726.

21. Gopel SO, Kanno T, Barg S, et al. (2000) Regulation of glucagon release in mouse $\alpha$-cells by $\mathrm{K}_{\mathrm{ATP}}$ channels and inactivation of TTX-sensitive $\mathrm{Na}^{+}$channels. $J$ Physiol 528, $509-520$

22. Tuduri E, Marroqui L, Soriano S, et al. (2009) Inhibitory effects of leptin on pancreatic $\alpha$-cell function. Diabetes 58, 1616-1624.

23. Taborsky GJ Jr, Ahren B \& Havel PJ (1998) Autonomic mediation of glucagon secretion during hypoglycemia: implications for impaired $\alpha$-cell responses in type 1 diabetes. Diabetes 47, 995-1005.

24. Thorens B (2011) Brain glucose sensing and neural regulation of insulin and glucagon secretion. Diabetes Obes Metab 13, Suppl. 1, 82-88.

25. Rorsman P, Salehi SA, Abdulkader F, et al. (2008) K(ATP)channels and glucose-regulated glucagon secretion. Trends Endocrinol Metab 19, 277-284.

26. MacDonald PE, De Marinis YZ, Ramracheya R, et al. (2007) A $K_{\text {ATP }}$ channel-dependent pathway within $\alpha$ cells regulates glucagon release from both rodent and human islets of Langerhans. PLoS Biol 5, e143.

27. Gylfe E (2013) Glucose control of glucagon secretion: there is more to it than $\mathrm{K}_{\mathrm{ATP}}$ channels. Diabetes 62, 1391-1393.

28. Liu YJ, Vieira E \& Gylfe E (2004) A store-operated mechanism determines the activity of the electrically excitable glucagon-secreting pancreatic $\alpha$-cell. Cell Calcium 35, 357-365.

29. Quoix N, Cheng-Xue R \& Mattart L (2009) Glucose and pharmacological modulators of ATP-sensitive $\mathrm{K}^{+}$channels control $\left[\mathrm{Ca}^{2+}\right]_{\mathrm{c}}$ by different mechanisms in isolated mouse $\alpha$-cells. Diabetes 58, 412-421.

30. Le Marchand SJ \& Piston DW (2010) Glucose suppression of glucagon secretion: metabolic and calcium responses from $\alpha$-cells in intact mouse pancreatic islets. $J$ Biol Chem 285, 14389-14398.

31. Ravier MA \& Rutter GA (2005) Glucose or insulin, but not zinc ions, inhibit glucagon secretion from mouse pancreatic $\alpha$-cells. Diabetes 54, 1789-1797.

32. Detimary P, Dejonghe S, Ling Z, et al. (1998) The changes in adenine nucleotides measured in glucose-stimulated rodent islets occur in $\beta$ cells but not in $\alpha$ cells and are also observed in human islets. J Biol Chem 273, 33905-33908.

33. Gorus FK, Malaisse WJ \& Pipeleers DG (1984) Differences in glucose handling by pancreatic A- and B-cells. $J$ Biol Chem 259, 1196-1200.

34. Heimberg H, De Vos A, Pipeleers D, et al. (1995) Differences in glucose transporter gene expression between rat pancreatic $\alpha$ - and $\beta$-cells are correlated to differences in glucose transport but not in glucose utilization. $J$ Biol Chem 270, 8971-8975.
35. Schuit F, De Vos A, Farfari S, et al. (1997) Metabolic fate of glucose in purified islet cells. Glucose-regulated anaplerosis in $\beta$ cells. J Biol Chem 272, 18572-18579.

36. Sekine S, Ito Y, Hashimoto M, et al. (1994) Characterization of monoclonal antibodies to chitinase A1 and enhancement of chitinase A1 activity by monoclonal antibodies. Biochem Biophys Res Commun 204, 7-16.

37. Zhao C, Wilson MC, Schuit F, et al. (2001) Expression and distribution of lactate/monocarboxylate transporter isoforms in pancreatic islets and the exocrine pancreas. Diabetes 50, 361-366.

38. Allister EM, Robson-Doucette CA, Prentice KJ, et al. (2013) UCP2 regulates the glucagon response to fasting and starvation. Diabetes 62, 1623-1633.

39. Cheng-Xue R, Gomez-Ruiz A, Antoine N, et al. (2013) Tolbutamide controls glucagon release from mouse islets differently than glucose: involvement of K(ATP) channels from both $\alpha$-cells and $\delta$-cells. Diabetes 62, 1612-1622.

40. da Silva Xavier G, Farhan H, Kim H, et al. (2011) Perarnt-sim (PAS) domain-containing protein kinase is downregulated in human islets in type 2 diabetes and regulates glucagon secretion. Diabetologia 54, 819-827.

41. Leclerc I, Sun G, Morris C, et al. (2011) AMP-activated protein kinase regulates glucagon secretion from mouse pancreatic $\alpha$ cells. Diabetologia 54, 125-134.

42. Vieira E, Marroquí L, Figueroa AC, et al. (2013) Involvement of the clock gene Rev-erb $\alpha$ in the regulation of glucagon secretion in pancreatic $\alpha$-cells. PLOS ONE 8, e69939.

43. Ellingsgaard H, Ehses JA, Hammar EB, et al. (2008) Interleukin-6 regulates pancreatic $\alpha$-cell mass expansion. Proc Natl Acad Sci U S A 105, 13163-13168.

44. Dumonteil E, Magnan C, Ritz-Laser B, et al. (2000) Glucose regulates proinsulin and prosomatostatin but not proglucagon messenger ribonucleic acid levels in rat pancreatic islets. Endocrinology 141, 174-180.

45. Kuhara T, Ikeda S, Ohneda A, et al. (1991) Effects of intravenous infusion of 17 amino acids on the secretion of $\mathrm{GH}$, glucagon, and insulin in sheep. Am J Physiol 260, E21-E26.

46. Pipeleers DG, Schuit FC, Van Schravendijk CF, et al. (1985) Interplay of nutrients and hormones in the regulation of glucagon release. Endocrinology 117, 817-823.

47. Ostenson CG (1985) Grebing C Evidence for metabolic regulation of pancreatic glucagon secretion by l-glutamine. Acta Endocrinol (Copenh) 108, 386-391.

48. Li XC, Liao TD \& Zhuo JL (2008) Long-term hyperglucagonaemia induces early metabolic and renal phenotypes of type 2 diabetes in mice. Clin Sci (Lond) 114, 591-601.

49. Gannon MC, Nuttall JA \& Nuttall FQ (2002) The metabolic response to ingested glycine. Am J Clin Nutr 76, 1302-1307.

50. Leclercq-Meyer V, Marchand J, Woussen-Colle MC, et al. (1985) Multiple effects of leucine on glucagon, insulin, and somatostatin secretion from the perfused rat pancreas. Endocrinology 116, 1168-1174.

51. Bode HP, Weber S, Fehmann HC, et al. (1999) A nutrientregulated cytosolic calcium oscillator in endocrine pancreatic glucagon-secreting cells. Pflugers Arch 437, 324-334.

52. Collins SC, Luan J, Thompson AJ, et al. (2007) Adiponectin receptor genes: mutation screening in syndromes of insulin resistance and association studies for type 2 diabetes and metabolic traits in UK populations. Diabetologia 50, $555-562$

53. Hong J, Abudula R, Chen J, et al. (2005) The shortterm effect of fatty acids on glucagon secretion is influenced by their chain length, spatial configuration, and degree of unsaturation: studies in vitro. Metabolism 54, 1329-1336 
54. Olofsson CS, Salehi A, Gopel SO, et al. (2004) Palmitate stimulation of glucagon secretion in mouse pancreatic $\alpha$-cells results from activation of 1-type calcium channels and elevation of cytoplasmic calcium. Diabetes $\mathbf{5 3}$, 2836-2843.

55. Bollheimer LC, Landauer HC, Troll S, et al. (2004) Stimulatory short-term effects of free fatty acids on glucagon secretion at low to normal glucose concentrations. Metabolism 53, 1443-1448.

56. Flodgren E, Olde B, Meidute-Abaraviciene S, et al. (2007) GPR40 is expressed in glucagon producing cells and affects glucagon secretion. Biochem Biophys Res Commun 354, $240-245$.

57. Wang L, Zhao Y, Gui B, et al. (2011) Acute stimulation of glucagon secretion by linoleic acid results from GPR 40 activation and $\left[\mathrm{Ca}^{2+}\right] \mathrm{i}$ increase in pancreatic islet $\alpha$-cells. J Endocrinol 210, 173-179.

58. Fujiwara K, Maekawa F, Dezaki K, et al. (2007) Oleic acid glucose-independently stimulates glucagon secretion by increasing cytoplasmic $\mathrm{Ca}^{2+}$ via endoplasmic reticulum $\mathrm{Ca}^{2+}$ release and $\mathrm{Ca}^{2+}$ influx in the rat islet $\alpha$-cells. Endocrinology 148, 2496-2504.

59. Hong J, Jeppesen PB, Nordentoft I, et al. (2007) Fatty acidinduced effect on glucagon secretion is mediated via fatty acid oxidation. Diabetes Metab Res Rev 23, 202-210.

60. Piro S, Maniscalchi ET, Monello A, et al. (2010) Palmitate affects insulin receptor phosphorylation and intracellular insulin signal in a pancreatic $\alpha$-cell line. Endocrinology 151, 4197-4206.

61. Gremlich S, Bonny C, Waeber G, et al. (1997) Fatty acids decrease IDX-1 expression in rat pancreatic islets and reduce GLUT2, glucokinase, insulin, and somatostatin levels. J Biol Chem 272, 30261-30269.

62. Bourlon PM, Faure-Dussert A, Billaudel B, et al. (1996) Relationship between calbindin-D28K levels in the A and $\mathrm{B}$ cells of the rat endocrine pancreas and the secretion of insulin and glucagon: influence of vitamin $\mathrm{D}_{3}$ deficiency and 1,25-dihydroxyvitamin $\mathrm{D}_{3}$. J Endocrinol 148, 223-232.

63. Orwoll E \& Riddle M (1994) Prince M Effects of vitamin D on insulin and glucagon secretion in non-insulin-dependent diabetes mellitus. Am J Clin Nutr 59, 1083-1087.

64. Chertow BS, Driscoll HK, Blaner WS, et al. (1994) Effects of vitamin A deficiency and repletion on rat glucagon secretion. Pancreas 9, 475-484.

65. Chertow BS, Driscoll HK, Primerano DA, et al. (1996) Retinoic acid receptor transcripts and effects of retinol and retinoic acid on glucagon secretion from rat islets and glucagon-secreting cell lines. Metabolism 45, 300-305.

66. Klandorf H \& Clarke BL (1987) Brown J Altered glucagon release in biotin deficiency. Gen Comp Endocrinol 65 , 133-140.

67. Wilkes LC, Bailey CJ, Thompson B, et al. (1990) Effect of gastrin-releasing peptide on the secretion of mouse islet hormones in vitro. J Endocrinol 127, 335-340.

68. Winzell MS (2007) Ahren B Role of VIP and PACAP in islet function. Peptides 28, 1805-1813.

69. Miralles P, Peiro E, Degano P, et al. (1990) Inhibition of insulin and somatostatin secretion and stimulation of glucagon release by homologous galanin in perfused rat pancreas. Diabetes 39, 996-1001.

70. De Marinis YZ, Salehi A, Ward CE, et al. (2010) GLP-1 inhibits and adrenaline stimulates glucagon release by differential modulation of $\mathrm{N}$ - and L-type $\mathrm{Ca}^{2+}$ channel-dependent exocytosis. Cell Metab 11, 543-553.

71. Cabrera O, Jacques-Silva MC, Speier S, et al. (2008) Glutamate is a positive autocrine signal for glucagon release. Cell Metab 7, 545-554.
72. Rodriguez-Diaz R, Dando R, Jacques-Silva MC, et al. (2011) $\alpha$ Cells secrete acetylcholine as a non-neuronal paracrine signal priming $\beta$ cell function in humans. Nat Med 17, 888-892.

73. Miki T, Liss B, Minami K, et al. (2001) ATP-sensitive $\mathrm{K}^{+}$ channels in the hypothalamus are essential for the maintenance of glucose homeostasis. Nat Neurosci 4, 507-512.

74. Leibiger B, Moede T, Muhandiramlage TP, et al. (2012) Glucagon regulates its own synthesis by autocrine signaling. Proc Natl Acad Sci U S A 109, 20925-20930.

75. Tuduri E, Filiputti E, Carneiro EM, et al. (2008) Inhibition of $\mathrm{Ca}^{2+}$ signaling and glucagon secretion in mouse pancreatic $\alpha$-cells by extracellular ATP and purinergic receptors. Am J Physiol Endocrinol Metab 294, E952-E960.

76. Ma X, Zhang Y, Gromada J, et al. (2005) Glucagon stimulates exocytosis in mouse and rat pancreatic $\alpha$-cells by binding to glucagon receptors. Mol Endocrinol 19 , 198-212.

77. Dunning BE \& Foley JE (2005) Ahren B $\alpha$ Cell function in health and disease: influence of glucagon-like peptide-1. Diabetologia 48, 1700-1713.

78. Ding WG, Renstrom E, Rorsman P, et al. (1997) Glucagonlike peptide I and glucose-dependent insulinotropic polypeptide stimulate $\mathrm{Ca}^{2+}$-induced secretion in rat $\alpha$-cells by a protein kinase A-mediated mechanism. Diabetes 46, $792-800$.

79. de Heer J, Rasmussen C, Coy DH, et al. (2008) Glucagonlike peptide-1, but not glucose-dependent insulinotropic peptide, inhibits glucagon secretion via somatostatin (receptor subtype 2) in the perfused rat pancreas. Diabetologia 51, 2263-2270.

80. Opara EC, Burch WM, Taylor IL, et al. (1991) Pancreatic hormone response to neuropeptide Y (NPY) perifusion in vitro. Regul Pept 34, 225-233.

81. Gosmain Y, Cheyssac C, et al. (2011) Glucagon gene expression in the endocrine pancreas: the role of the transcription factor Pax6 in $\alpha$-cell differentiation, glucagon biosynthesis and secretion. Diabetes Obes Metab 13, Suppl. 1, 31-38.

82. Jin $\mathrm{T}$ (2008) Mechanisms underlying proglucagon gene expression. J Endocrinol 198, 17-28.

83. Mojsov S, Heinrich G, Wilson IB, et al. (1986) Preproglucagon gene expression in pancreas and intestine diversifies at the level of post-translational processing. J Biol Chem 261, 11880-11889.

84. Dey A, Lipkind GM, Rouille Y, et al. (2005) Significance of prohormone convertase 2, PC2, mediated initial cleavage at the proglucagon interdomain site, Lys70-Arg71, to generate glucagon. Endocrinology 146, 713-727.

85. Patzelt C \& Schiltz E (1984) Conversion of proglucagon in pancreatic $\alpha$ cells: the major endproducts are glucagon and a single peptide, the major proglucagon fragment, that contains two glucagon-like sequences. Proc Natl Acad Sci U S A 81, 5007-5011.

86. Patzelt C, Tager HS, Carroll RJ, et al. (1979) Identification and processing of proglucagon in pancreatic islets. Nature 282, 260-266.

87. Furuta M, Zhou A, Webb G, et al. (2001) Severe defect in proglucagon processing in islet A-cells of prohormone convertase 2 null mice. J Biol Chem 276, 27197-27202.

88. Dumonteil E, Ritz-Laser B, Magnan C, et al. (1999) Chronic exposure to high glucose concentrations increases proglucagon messenger ribonucleic acid levels and glucagon release from InR1G9 cells. Endocrinology 140, 4644-4650.

89. McGirr R, Ejbick CE, Carter DE, et al. (2005) Glucose dependence of the regulated secretory pathway in $\alpha \mathrm{TC} 1-$ 6 cells. Endocrinology 146, 4514-4523. 
90. Grzeskowiak R, Amin J, Oetjen E, et al. (2000) Insulin responsiveness of the glucagon gene conferred by interactions between proximal promoter and more distal enhancer-like elements involving the paired-domain transcription factor Pax6. J Biol Chem 275, 30037-30045.

91. Philippe J (1989) Glucagon gene transcription is negatively regulated by insulin in a hamster islet cell line. J Clin Invest 84, 672-677.

92. Schinner S, Barthel A, Dellas C, et al. (2005) Protein kinase $B$ activity is sufficient to mimic the effect of insulin on glucagon gene transcription. J Biol Chem 280, 7369-7376.

93. Yamato E, Noma Y, Tahara Y, et al. (1990) Suppression of synthesis and release of glucagon by glucagon-like peptide-1 (7-36 amide) without affect on mRNA level in isolated rat islets. Biochem Biophys Res Commun 167, 431-437.

94. Paul GL, Waegner A, Gaskins HR, et al. (1998) Histidine availability alters glucagon gene expression in murine aTC6 cells. J Nutr 128, 973-976.

95. Mayo KE, Miller LJ, Bataille D, et al. (2003) International Union of Pharmacology. XXXV. The glucagon receptor family. Pharmacol Rev 55, 167-194.

96. Weinstein LS, Yu S, Warner DR, et al. (2001) Endocrine manifestations of stimulatory $\mathrm{G}$ protein $\alpha$-subunit mutations and the role of genomic imprinting. Endocr Rev $\mathbf{2 2}$ 675-705.

97. Kimball SR, Siegfried BA \& Jefferson LS (2004) Glucagon represses signaling through the mammalian target of rapamycin in rat liver by activating AMP-activated protein kinase. J Biol Chem 279, 54103-54109.

98. Chen J, Ishac EJ, Dent P, et al. (1998) Effects of ethanol on mitogen-activated protein kinase and stress-activated protein kinase cascades in normal and regenerating liver. Biochem J 334, 669-676.

99. Svoboda M, Tastenoy M, Vertongen P, et al. (1994) Relative quantitative analysis of glucagon receptor mRNA in rat tissues. Mol Cell Endocrinol 105, 131-137.

100. Kedees MH, Grigoryan M, Guz Y, et al. (2009) Differential expression of glucagon and glucagon-like peptide 1 receptors in mouse pancreatic $\alpha$ and $\beta$ cells in two models of $\alpha$ cell hyperplasia. Mol Cell Endocrinol 311, 69-76.

101. Kieffer TJ, Heller RS, Unson CG, et al. (1996) Distribution of glucagon receptors on hormone-specific endocrine cells of rat pancreatic islets. Endocrinology 137, 5119-5125.

102. Gelling RW, Du XQ, Dichmann DS, et al. (2003) Lower blood glucose, hyperglucagonemia, and pancreatic $\alpha$ cell hyperplasia in glucagon receptor knockout mice. Proc Natl Acad Sci US A 100, 1438-1443.

103. Conarello SL, Jiang G, Mu J, et al. (2007) Glucagon receptor knockout mice are resistant to diet-induced obesity and streptozotocin-mediated $\beta$ cell loss and hyperglycaemia. Diabetologia 50, 142-150.

104. Lee Y, Wang MY, Du XQ, et al. (2011) Glucagon receptor knockout prevents insulin-deficient type 1 diabetes in mice. Diabetes 60, 391-397.

105. Sorensen H, Winzell MS, Brand CL, et al. (2006) Glucagon receptor knockout mice display increased insulin sensitivity and impaired $\beta$-cell function. Diabetes 55, 3463-3469.

106. Vuguin PM, Kedees MH, Cui L, et al. (2006) Ablation of the glucagon receptor gene increases fetal lethality and produces alterations in islet development and maturation. Endocrinology 147, 3995-4006.

107. Gelling RW, Vuguin PM, Du XQ, et al. (2009) Pancreatic $\beta$-cell overexpression of the glucagon receptor gene results in enhanced $\beta$-cell function and mass. Am J Physiol Endocrinol Metab 297, E695-E707.
108. Berglund ED, Lustig DG, Baheza RA, et al. (2011) Hepatic glucagon action is essential for exercise-induced reversal of mouse fatty liver. Diabetes 60, 2720-2729.

109. Jones BJ, Tan T \& Bloom SR (2012) Minireview: glucagon in stress and energy homeostasis. Endocrinology 153, 1049-1054.

110. Yoon JC, Puigserver P, Chen G, et al. (2001) Control of hepatic gluconeogenesis through the transcriptional coactivator PGC-1. Nature 413, 131-138.

111. Hjorth SA, Adelhorst K, Pedersen BB, et al. (1994) Glucagon and glucagon-like peptide 1: selective receptor recognition via distinct peptide epitopes. J Biol Chem 269, 30121-30124

112. Herzig S, Long F, Jhala US, et al. (2001) CREB regulates hepatic gluconeogenesis through the coactivator PGC-1. Nature 413, 179-183.

113. Band GC \& Jones CT (1980) Functional activation by glucagon of glucose 6-phosphatase and gluconeogenesis in the perfused liver of the fetal guinea pig. FEBS Lett 119, 190-194.

114. De Oya M, Prigge WF \& Grande F (1971) Suppression by hepatectomy of glucagon-induced hypertriglyceridemia in geese. Proc Soc Exp Biol Med 136, 107-110.

115. Penhos JC, Wu CH, Daunas J, et al. (1966) Effect of glucagon on the metabolism of lipids and on urea formation by the perfused rat liver. Diabetes 15, 740-748.

116. Aubry F, Marcel YL \& Davignon J (1974) Effects of glucagon on plasma lipids in different types of primary hyperlipoproteinemia. Metabolism 23, 225-238.

117. Eaton RP (1973) Hypolipemic action of glucagon in experimental endogenous lipemia in the rat. J Lipid Res 14, 312-318.

118. Charbonneau A, Couturier K, Gauthier MS, et al. (2005) Evidence of hepatic glucagon resistance associated with hepatic steatosis: reversal effect of training. Int $J$ Sports Med 26, 432-441.

119. Charbonneau A, Melancon A, Lavoie C, et al. (2005) Alterations in hepatic glucagon receptor density and in $G_{\mathrm{s}} \alpha$ and $\mathrm{G}_{\mathrm{i}} \alpha 2$ protein content with diet-induced hepatic steatosis: effects of acute exercise. Am J Physiol Endocrinol Metab 289, E8-E14.

120. Han S, Akiyama TE, Previs SF, et al. (2013) Effects of siRNA-mediated hepatic glucagon receptor inhibition on lipid metabolism in db/db mice. J Lipid Res 54, 2615-2622.

121. Cynober LA (2002) Plasma amino acid levels with a note on membrane transport: characteristics, regulation, and metabolic significance. Nutrition 18, 761-766.

122. Hoosein NM \& Gurd RS (1984) Identification of glucagon receptors in rat brain. Proc Natl Acad Sci US A 81, 4368-4372.

123. Cockram CS, Kum W, Ho SK, et al. (1995) Binding and action of glucagon in cultured mouse astrocytes. Glia 13, 141-146.

124. Inokuchi A, Oomura Y \& Nishimura H (1984) Effect of intracerebroventricularly infused glucagon on feeding behavior. Physiol Behav 33, 397-400.

125. Amir S (1986) Central glucagon-induced hyperglycemia is mediated by combined activation of the adrenal medulla and sympathetic nerve endings. Physiol Behav 37, 563-566.

126. Geary N \& Smith GP (1983) Selective hepatic vagotomy blocks pancreatic glucagon's satiety effect. Physiol Behav 31, 391-394.

127. Geary N \& Smith GP (1982) Pancreatic glucagon and postprandial satiety in the rat. Physiol Behav 28, 313-322.

128. Martin JR \& Novin D (1977) Decreased feeding in rats following hepatic-portal infusion of glucagon. Physiol Behav 19, 461-466. 
129. Penick SB \& Hinkle LE Jr (1961) Depression of food intake induced in healthy subjects by glucagon. N Engl J Med $\mathbf{2 6 4}$, 893-897.

130. Woods SC, Lutz TA, Geary N, et al. (2006) Pancreatic signals controlling food intake; insulin, glucagon and amylin. Philos Trans R Soc Lond B Biol Sci 361, 1219-1235.

131. Langhans W, Zeiger U, Scharrer E, et al. (1982) Stimulation of feeding in rats by intraperitoneal injection of antibodies to glucagon. Science 218, 894-896.

132. Jensen PB, Blume N, Mikkelsen JD, et al. (1998) Transplantable rat glucagonomas cause acute onset of severe anorexia and adipsia despite highly elevated NPY mRNA levels in the hypothalamic arcuate nucleus. J Clin Invest 101, 503-510.

133. Arafat AM, Perschel FH, Otto B, et al. (2006) Glucagon suppression of ghrelin secretion is exerted at hypothalamuspituitary level. J Clin Endocrinol Metab 91, 3528-3533.

134. Mighiu PI, Yue JT, Filippi BM, et al. (2013) Hypothalamic glucagon signaling inhibits hepatic glucose production. Nat Med 19, 766-772.

135. Davidson IW, Salter JM \& Best CH (1957) Calorigenic action of glucagon. Nature 180, 1124.

136. Nair KS (1987) Hyperglucagonemia increases resting metabolic rate in man during insulin deficiency. $J$ Clin Endocrinol Metab 64, 896-901.

137. Calles-Escandon J (1994) Insulin dissociates hepatic glucose cycling and glucagon-induced thermogenesis in man. Metabolism 43, 1000-1005.

138. Tan TM, Field BC, McCullough KA, et al. (2013) Coadministration of glucagon-like peptide-1 during glucagon infusion in humans results in increased energy expenditure and amelioration of hyperglycemia. Diabetes $\mathbf{6 2}$, $1131-1138$

139. Billington CJ, Briggs JE, Link JG, et al. (1991) Glucagon in physiological concentrations stimulates brown fat thermogenesis in vivo. Am J Physiol 261, R501-R507.

140. Joel CD (1966) Stimulation of metabolism of rat brown adipose tissue by addition of lipolytic hormones in vitro. I Biol Chem 241, 814-821.

141. Yahata T \& Kuroshima A (1982) Influence of endocrine and chemical factors on glucagon induced thermogenesis in brown adipocytes. Ipn I Physiol 32, 303-307.

142. Billington CJ, Bartness TJ, Briggs J, et al. (1987) Glucagon stimulation of brown adipose tissue growth and thermogenesis. Am J Physiol 252, R160-R165.

143. Filali-Zegzouti Y, Abdelmelek H, Rouanet JL, et al. (2005) Role of catecholamines in glucagon-induced thermogenesis. J Neural Transm 112, 481-489.

144. Dicker A, Zhao J, Cannon B, et al. (1998) Apparent thermogenic effect of injected glucagon is not due to a direct effect on brown fat cells. Am J Physiol 275, R1674-R1682.

145. Schulman JL, Carleton JL, Whitney G, et al. (1957) Effect of glucagon on food intake and body weight in man. $J A p p l$ Physiol 11, 419-421.

146. Chan EK, Mackey MA, Snover DC, et al. (1984) Suppression of weight gain by glucagon in obese Zucker rats. Exp Mol Pathol 40, 320-327.

147. Habegger KM, Stemmer K, Cheng C, et al. (2013) Fibroblast growth factor 21 mediates specific glucagon actions. Diabetes 62, 1453-1463.

148. Liu Z, Kim W, Chen Z, et al. (2011) Insulin and glucagon regulate pancreatic $\alpha$-cell proliferation. PLOS ONE 6, e16096.

149. Moens K, Heimberg H, Flamez D, et al. (1996) Expression and functional activity of glucagon, glucagon-like peptide $\mathrm{I}$, and glucose-dependent insulinotropic peptide receptors in rat pancreatic islet cells. Diabetes 45, 257-261.
150. Mery PF, Brechler V, Pavoine C, et al. (1990) Glucagon stimulates the cardiac $\mathrm{Ca}^{2+}$ current by activation of adenylyl cyclase and inhibition of phosphodiesterase. Nature $\mathbf{3 4 5}$, $158-161$.

151. Gonzalez-Munoz C, Nieto-Ceron S, Cabezas-Herrera J, et al. (2008) Glucagon increases contractility in ventricle but not in atrium of the rat heart. Eur J Pharmacol $\mathbf{5 8 7}$, $243-247$.

152. Harney JA \& Rodgers RL (2008) Insulin-like stimulation of cardiac fuel metabolism by physiological levels of glucagon: involvement of PI3K but not cAMP. Am J Physiol Endocrinol Metab 295, E155-E161.

153. Heckemeyer CM, Barker J, Duckworth WC, et al. (1983) Studies of the biological effect and degradation of glucagon in the rat perifused isolated adipose cell. Endocrinology 113, 270-276.

154. Perea A, Clemente F, Martinell J, et al. (1995) Physiological effect of glucagon in human isolated adipocytes. Horm Metab Res 27, 372-375.

155. Gravholt CH, Moller N, Jensen MD, et al. (2001) Physiological levels of glucagon do not influence lipolysis in abdominal adipose tissue as assessed by microdialysis. J Clin Endocrinol Metab 86, 2085-2089.

156. Lefebvre P, Luyckx A \& Bacq ZM (1973) Effects of denervation on the metabolism and the response to glucagon of white adipose tissue of rats. Horm Metab Res 5, 245-250.

157. Ahloulay M, Bouby N, Machet F, et al. (1992) Effects of glucagon on glomerular filtration rate and urea and water excretion. Am J Physiol 263, F24-F36.

158. Yano Y, Cesar KR, Araujo M, et al. (2009) Aquaporin 2 expression increased by glucagon in normal rat inner medullary collecting ducts. Am J Physiol Renal Physiol 296, F54-F59.

159. Gutzeit A, Binkert CA, Koh DM, et al. (2012) Evaluation of the anti-peristaltic effect of glucagon and hyoscine on the small bowel: comparison of intravenous and intramuscular drug administration. Eur Radiol 22, 1186-1194.

160. Mochiki E, Suzuki H, Takenoshita S, et al. (1998) Mechanism of inhibitory effect of glucagon on gastrointestinal motility and cause of side effects of glucagon. J Gastroenterol 33, 835-841.

161. Amanda B, Manuela M, Antonia M, et al. (2010) Posturography measures and efficacy of different physical treatments in somatic tinnitus. Int Tinnitus J 16, 44-50.

162. Larsson H (2000) Ahren B Islet dysfunction in insulin resistance involves impaired insulin secretion and increased glucagon secretion in postmenopausal women with impaired glucose tolerance. Diabetes Care 23, 650-657.

163. Reaven GM, Chen YD, Golay A, et al. (1987) Documentation of hyperglucagonemia throughout the day in nonobese and obese patients with noninsulin-dependent diabetes mellitus. I Clin Endocrinol Metab 64, 106-110.

164. Sherwin R, Wahren J \& Felig P (1976) Evanescent effects of hypo- and hyperglucagonemia on blood glucose homeostasis. Metabolism 25, 1381-1383.

165. Gastaldelli A, Baldi S, Pettiti M, et al. (2000) Influence of obesity and type 2 diabetes on gluconeogenesis and glucose output in humans: a quantitative study. Diabetes $\mathbf{4 9}$ $1367-1373$

166. Siafarikas A, Johnston RJ, Bulsara MK, et al. (2012) Early loss of the glucagon response to hypoglycemia in adolescents with type 1 diabetes. Diabetes Care 35, 1757-1762.

167. Dinneen S, Alzaid A, Turk D, et al. (1995) Failure of glucagon suppression contributes to postprandial hyperglycaemia in IDDM. Diabetologia 38, 337-343.

168. Shah P, Vella A, Basu A, et al. (2000) Lack of suppression of glucagon contributes to postprandial hyperglycemia in 
subjects with type 2 diabetes mellitus. J Clin Endocrinol Metab 85, 4053-4059.

169. Eldor R, Glaser B, Fraenkel M, et al. (2011) Glucagonoma and the glucagonoma syndrome - cumulative experience with an elusive endocrine tumour. Clin Endocrinol (Oxf) 74, 593-598.

170. Bolli G, De Feo P, Perriello G, et al. (1984) Mechanisms of glucagon secretion during insulin-induced hypoglycemia in man. Role of the $\beta$ cell and arterial hyperinsulinemia.J Clin Invest 73, 917-922.

171. Zhou H, Zhang T, Harmon JS, et al. (2007) Zinc, not insulin, regulates the rat $\alpha$-cell response to hypoglycemia in vivo. Diabetes 56, 1107-1112.

172. Zhou H, Zhang T, Oseid E, et al. (2007) Reversal of defective glucagon responses to hypoglycemia in insulindependent autoimmune diabetic BB rats. Endocrinology 148, 2863-2869.

173. Deng S, Vatamaniuk M, Huang X, et al. (2004) Structural and functional abnormalities in the islets isolated from type 2 diabetic subjects. Diabetes 53, 624-632.

174. Henquin JC \& Rahier J (2011) Pancreatic $\alpha$ cell mass in European subjects with type 2 diabetes. Diabetologia $\mathbf{5 4}$, $1720-1725$.

175. Yoon KH, Ko SH, Cho JH, et al. (2003) Selective $\beta$-cell loss and $\alpha$-cell expansion in patients with type 2 diabetes mellitus in Korea. J Clin Endocrinol Metab 88, 2300-2308.

176. Charlton MR, Adey DB \& Nair KS (1996) Evidence for a catabolic role of glucagon during an amino acid load. J Clin Invest 98, 90-99.

177. Tessari P, Inchiostro S, Barazzoni R, et al. (1996) Hyperglucagonemia stimulates phenylalanine oxidation in humans. Diabetes 45, 463-470.

178. Roth E, Muhlbacher F, Karner J, et al. (1987) Free amino acid levels in muscle and liver of a patient with glucagonoma syndrome. Metabolism 36, 7-13.

179. Charlton MR \& Nair KS (1998) Role of hyperglucagonemia in catabolism associated with type 1 diabetes: effects on leucine metabolism and the resting metabolic rate. Diabetes 47, 1748-1756.

180. Boden G, Rezvani I \& Owen OE (1984) Effects of glucagon on plasma amino acids. J Clin Invest 73, 785-793

181. Slavin BG, Ong JM \& Kern PA (1994) Hormonal regulation of hormone-sensitive lipase activity and mRNA levels in isolated rat adipocytes. J Lipid Res 35, 1535-1541.

182. Guettet C, Rostaqui N, Mathe D, et al. (1991) Effect of chronic glucagon administration on lipoprotein composition in normally fed, fasted and cholesterol-fed rats. Lipids 26, 451-458.

183. Guettet C, Rostaqui N, Navarro N, et al. (1991) Effect of chronic glucagon administration on the metabolism of triacylglycerol-rich lipoproteins in rats fed a high sucrose diet. J Nutr 121, 24-30.

184. Beylot M, Picard S, Chambrier C, et al. (1991) Effect of physiological concentrations of insulin and glucagon on the relationship between nonesterified fatty acids availability and ketone body production in humans. Metabolism 40, 1138-1146.

185. Miles JM, Haymond MW, Nissen SL, et al. (1983) Effects of free fatty acid availability, glucagon excess, and insulin deficiency on ketone body production in postabsorptive man. J Clin Invest 71, 1554-1561.

186. Okuda Y, Kawai K \& Yamashita K (1987) Age-related change in ketone body metabolism: diminished glucagon effect on ketogenesis in adult rats. Endocrinology 120, 2152-2157.
187. Taborsky GJ Jr (2010) The physiology of glucagon. J Diabetes Sci Technol 4, 1338-1344.

188. Wahid M, Naveed AK \& Hussain I (2006) Insulin and glucagon ratio in the patho-physiology of diabetic ketoacidosis and hyperosmolar hyperglycemic non-ketotic diabetes. J Coll Physicians Surg Pak 16, 11-14.

189. Hancock AS, Du A, Liu J, et al. (2010) Glucagon deficiency reduces hepatic glucose production and improves glucose tolerance in adult mice. Mol Endocrinol 24, 1605-1614.

190. Lee Y, Berglund ED, Wang MY, et al. (2012) Metabolic manifestations of insulin deficiency do not occur without glucagon action. Proc Natl Acad Sci U S A 109, $14972-14976$

191. Sinclair EM, Yusta B, Streutker C, et al. (2008) Glucagon receptor signaling is essential for control of murine hepatocyte survival. Gastroenterology 135, 2096-2106.

192. Parker JC, McPherson RK, Andrews KM, et al. (2000) Effects of skyrin, a receptor-selective glucagon antagonist, in rat and human hepatocytes. Diabetes 49, 2079-2086.

193. Petersen KF \& Sullivan JT (2001) Effects of a novel glucagon receptor antagonist (Bay 27-9955) on glucagonstimulated glucose production in humans. Diabetologia 44, 2018-2024.

194. Sloop KW, Cao JX, Siesky AM, et al. (2004) Hepatic and glucagon-like peptide-1-mediated reversal of diabetes by glucagon receptor antisense oligonucleotide inhibitors. J Clin Invest 113, 1571-1581.

195. Winzell MS, Brand CL, Wierup N, et al. (2007) Glucagon receptor antagonism improves islet function in mice with insulin resistance induced by a high-fat diet. Diabetologia 50, $1453-1462$

196. Miller RA, Chu Q, Xie J, et al. (2013) Biguanides suppress hepatic glucagon signalling by decreasing production of cyclic AMP. Nature 494, 256-260.

197. Day JW, Ottaway N, Patterson JT, et al. (2009) A new glucagon and GLP-1 co-agonist eliminates obesity in rodents. Nat Chem Biol 5, 749-757.

198. Pocai A, Carrington PE, Adams JR, et al. (2009) Glucagonlike peptide 1 /glucagon receptor dual agonism reverses obesity in mice. Diabetes 58, 2258-2266.

199. Parker JA, McCullough KA, Field BC, et al. (2013) Glucagon and GLP-1 inhibit food intake and increase c-fos expression in similar appetite regulating centres in the brainstem and amygdala. Int J Obes (Lond) 37, 1391-1398.

200. Nauck MA, Heimesaat MM, Behle K, et al. (2002) Effects of glucagon-like peptide 1 on counterregulatory hormone responses, cognitive functions, and insulin secretion during hyperinsulinemic, stepped hypoglycemic clamp experiments in healthy volunteers. J Clin Endocrinol Metab 87, 1239-1246.

201. Dupre J, Behme MT \& McDonald TJ (2004) Exendin-4 normalized postcibal glycemic excursions in type 1 diabetes. J Clin Endocrinol Metab 89, 3469-3473.

202. Edgerton DS, Johnson KM \& Cherrington AD (2009) Current strategies for the inhibition of hepatic glucose production in type 2 diabetes. Front Biosci 14, 1169-1181.

203. Balas B, Baig MR, Watson C, et al. (2007) The dipeptidyl peptidase IV inhibitor vildagliptin suppresses endogenous glucose production and enhances islet function after single-dose administration in type 2 diabetic patients. J Clin Endocrinol Metab 92, 1249-1255.

204. Lebovitz HE (2010) Adjunct therapy for type 1 diabetes mellitus. Nat Rev Endocrinol 6, 326-334. 